This is a postprint version of the article:

Nurmi, J., Kaskela, T., Perälä, J., \& Oksanen, A. Seller's Reputation and Capacity on the Illicit Drug Markets: 11-Month Study on the Finnish Version of the Silk Road. Drug and Alcohol Dependence, 2017, vol. 178, pp. 201-207. DOI: 10.1016/j.drugalcdep.2017.05.018.

http://www.drugandalcoholdependence.com/article/S0376-8716(17)30291-0/pdf

\title{
Seller's Reputation and Capacity on the Illicit Drug Markets: 11-Month Study in the Finnish Version of the Silk Road
}

\begin{abstract}
Aims: This 11-month study analysed illicit drug sales on the anonymous Tor network, with a focus on investigating whether a seller's reputation and capacity increased daily drug sales. Design and setting: The data was gathered from Silkkitie, the Finnish version of the Silk Road, by web crawling the site on a daily basis from November 2014 to September 2015). The data includes information on sellers $(n=260)$ and products $(n=3823)$. Measurements: The measurements include the sellers' reputation, the sale amounts (in euros), the number of available products and the types of drugs sold. The sellers' capacity was measured using their full sales potential (in euros). Fixed-effects regression models were used to estimate the effects of sellers' reputation and capacity; these models were adjusted for the types of drugs sold. Findings: Overall, illicit drug sales totalled over 2 million euros during the study, but many products were not sold at all, and sellers were active for only a short time on average (mean=62.8 days). Among the products sold, stimulants were most widely purchased, followed by cannabis, MDMA, and psychedelics. A seller's reputation and capacity were both associated with drug sales. Conclusion: The Tor network has enabled a transformation in drug sales. Due to the network's anonymity, the seller's reputation and capacity both have an impact on sales.
\end{abstract}

Key words: illicit drugs, cryptomarket, Internet, Tor network, anonymity, longitudinal, web crawling

\section{Introduction}

Illicit online drug sales first attracted major media attention with the rise and fall of the Silk Road in 2011-2013 (Barratt et al., 2014; Martin, 2014a; Martin, 2014b). The Federal Bureau of Investigation shut down the Silk Road in October 2013 and its successor, the Silk Road 2, in November 2014 (Dolliver, 2015). The Silk Road 3 was launched almost immediately after but was overrun by other sites, such as Agora and Evolution, which adopted some features of the original Silk Road (Dolliver et al., 2016; Van Buskirk et al., 2016). The common feature of all of these websites is that they protect the anonymity of their users; they are hence referred to as "cryptomarkets" (Aldridge and Décary-Hétu, 2016; Bancroft and Reid, 2017; Demant et al., 2016; Martin, 2014b; Van Buskirk et al., 2016). This article focuses particularly on the Finnish online service called Silkkitie.

Silkkitie operates using the Tor network to hide its real location, just as Agora and various Silk Road versions did. The Tor (which stands for The Onion Router) network and software are designed to defend 
human rights (Dingledine, 2004). This network can be used for censorship circumvention, online anonymity and high-level online privacy. It is possible to host a website inside the Tor network (a socalled onion service) and to hide the physical location of the site's server. Tor provides anonymity by routing the user's traffic through three separate relay servers so that it is difficult to reveal the user's physical location or IP address. This means that Tor protects users by encryption to ensure privacy, authentication between clients and relays and signatures to ensure that all clients know the same set of relays.

Tor is considered very secure and resilient against surveillance: The U.S. National Security Agency called Tor "the king of high-secure, low-latency Internet anonymity" (The Guardian, 2013) in its top-secret documentation, in which it discusses its futile attempts to spy on Tor users. Despite this, different police operations have targeted sites and have at least been partially successful in reducing the activity in cryptomarkets (Décary-Hétu and Giommoni, 2017). Also, the identity of the original Silk Road developer, Ross William Ulbrich, was discovered after the FBI followed his behaviour pattern and gathered cumulative critical information for long enough (FBI, 2014).

The anonymity of online drug markets is guaranteed by digital currencies and payment systems that significantly increase the difficulty of tracking down buyers and sellers. Bitcoin is one digital currency and a payment system in one; it was invented by an unknown entity who calls himself Satoshi Nakamoto (Nakamoto, 2008; Bohannon, 2016; Kristoufek, 2015). Bitcoin is a peer-to-peer application that allows digital money transfers between users. Its monetary system is decentralised and designed to work without central banks, governments and regulations. Although Bitcoins are used in multiple legal ways, these anonymity properties also make Bitcoin attractive to criminals.

The work on illicit cryptomarkets has expanded rapidly since 2015. Many of the studies have been based on the Silk Road (e.g., Alridge and Décary-Hétu, 2016; Barratt and Maddox, 2016) and their successors, such as the Silk Road 2.0, Agora, Alphabay and Valhalla (e.g., Van Buskirk et al., 2016; Décary-Hétu and Giommoni, 2017; Demant et al., 2016; Dolliver and Kuhns, 2016; Van Hout and Hearne, 2017). Studies have employed more traditional research methods such as surveys and interviews (Barratt et al., 2014; Van Hout \& Bingham 2013a, b) and newer approaches employing web crawlers (Alridge and DécaryHétu, 2016; Demant et al., 2016; Dolliver, 2015; Dolliver et al., 2016; Aldridge, 2016; Christin, 2013; Hardy and Norgaard, 2015; Munksgaard et al., 2016). Some studies have also investigated the quality of drugs sold in the cryptomarkets (Caudeville et al., 2016; Rhumorbarbe al al., 2016). There is also currently a need to understand that cryptomarkets are also used very locally, as in our Finnish case. So far country cases have involved, for example, Canada (Broséus et al., 2016) and Switzerland (Rhumorbarbe et al., 2016), and some studies have involved cross-national comparison (Van Buskirk et al., 2016).

Studies on the Silk Road indicate that users were typically males in their 20s and prioritised the Silk Road over street markets for quality reasons and for personal safety (Barratt et al., 2014; Van Hout and Bingham, 2013b; Barratt et al., 2016a, Barratt et al., 2016b). Cryptomarket users have been characterised as a "technological drug subculture" (Van Hout and Bingham, 2013b), which also represents a form of online activism underlining individual freedoms based on libertarian ethos (Maddox et al., 2016; Munksgaard and Demant, 2016). Users' right to choose is combined with the expressed joy of having the opportunity to choose their preferred drugs like "kids in a candy store" (Barratt et al., 2016b).

As cryptomarkets are organised to guarantee the full anonymity of the users, they also bring challenges for the users. Social psychologists have underlined that anonymous behaviour can be highly regulated on the Internet (Keipi and Oksanen, 2014; Spears et al., 2002). In cryptomarkets, anonymity is enforced by instability, which may even enforce the anonymity effects of online behaviour. Instability is one of the 
central features of online drug markets, as most items are sold quickly and the majority of sellers disappear within a few months (Christin, 2013). Hence, there is a need for building "reputation systems" (Resnick, 2000; Houser and Wooders, 2006) or "trust systems" (Lusthaus, 2012) on cryptomarkets. Public user feedback is one of the common parts of such reputation or trust systems.

A previous study by Hardy and Norgaard (2015) showed that seller reputation had a positive impact on cannabis sales. They argue that users' feedback is a central feature in cannabis sales on the Silk Road because sellers and buyers do not know each other. Positive reputation gives the impression that the seller is trustworthy, which leads to increased sales (Hardy and Norgaard, 2015). It has also been found that vendors who had poor user ratings were more likely to take the risk of shipping drugs internationally (Décary-Hétu et al., 2016). Besides user feedback, it is often important to communicate well with the customer and create an impression of trustworthiness. According to Décary-Hétu and Leppänen, successful online criminals have communicative skills that lead to higher rewards (Décary-Hétu and Leppänen, 2013).

In the absence of visual cues that are typically available in an offline context, online buyers must rely on what information is available, which also separates online cryptomarkets from the traditional drug trade. We argue here, in addition to the seller's reputation, that seller's apacity is another potential factor of successful sales. Seller's capacity refers to sellers' promises regarding the variety and quantity of highquality products available. This is part of communication with the customers. Seller's capacity or promise of a lot of drugs in stock will create positive expectations that will lead to higher sales. It is common for cybercriminals to construct an online identity and create trustworthiness to attract criminal partners (Lusthaus, 2012). Seller's capacity is part of this communication, but it has not been previously studied with regard to cryptomarkets. However, economic studies on advance selling have shown that seller capacity is positively associated with consumer behaviour (Yu et al., 2015).

In this study, our aim was to research both the seller's reputation and capacity in Silkkitie. We will first provide descriptive results on the general drug sales on Silkkitie. The main focus of the article lies, however, on the reputation and capacity that represent different facets of the seller that are available to buyers. Anonymity directs users' attention to the available features and typically also enforces group behaviour (Keipi and Oksanen, 2014; Spears et al., 2002). Hence, in cryptomarket, trust system is based on both direct feedback and successful communication (Hardy and Norgaard, 2015; Resnick, 2000; Houser and Wooders, 2006; Décary-Hétu and Leppänen, 2013; Lusthaus, 2012). Our hypotheses were grounded on these premises, and we expected that a positive seller reputation would be positively associated with that entity's daily sales. In addition, we expected that an increase in a seller's capacity would increase that entity's sales.

\section{Methods}

\subsection{Silkkitie as a marketplace}

Silkkitie was opened in the Tor network on 6 January 2014, and it was originally intended to be used specifically for illicit drug sales in Finland. Because both the seller and the buyer are located within Finland, even detecting the drugs is difficult because there is no customs process for screening domestic shipments. For these reasons, virtually all of the Finnish sellers mention that the shipments are posted via domestic mail. As Silkkitie is the main online marketplace for Finnish drug buyers, it is a useful measure of the overall Finnish online drug market. In 2015, Silkkitie published the English translation of the site to attract user space outside Finland. The original Finnish version (http://silkkitiehdg5mug.onion/) now 
has an English translation called Valhalla (http://valhallaxmn3fydu.onion/). Bitcoin currency and the Bitcoin wallet system are used for payment, and Silkkitie requires sellers to use PGP encryption (Pretty Good Privacy, see Zimmerman 1995) and offer their public keys to buyers for encrypted and safe text communication. Silkkitie shows prices in euros and Bitcoins using the latest exchange rate. We have collected transaction data in terms of euros.

After Silkkitie users have created their user accounts on the service, they may select a role as a seller, which enables them to offer products on sale. The sellers may then set the price and describe both the product and the terms of the delivery. The seller's reputation is a central feature on Silkkitie (see Figure 1). Buyers can give feedback by rating the product and the transaction (good: + or bad: - ). Buyers see this feedback, so sellers have to keep up their reputations. More importantly, Silkkitie offers escrow service by holding the Bitcoins used for purchase and returning them to buyers if there is a lot of negative feedback. This makes it very important for sellers to build good reputations.

\subsection{Web-crawling process}

We employed automatic web-crawling and web-scraping techniques to extract information from the Silkkitie site every day between 5 November 2014 and 23 September 2015. This method is similar to the one that was developed to study the Silk Road's transactions (Christin, 2013). From a wider perspective, we are using the Open Source Intelligence methodology (Glassman and Kang, 2012). Our method is simple and very precise. Our web-scraping software extracted the product information from every product page on Silkkitie. The collected fields were title, price, number of items in stock, seller's nickname, seller's positive and negative feedback, seller's country, buyer's country and the product page's unique URL.

We executed the software once a day over a period of almost 11 months (322 days). Once a day is enough to study day-to-day drug trade. During our data collection period, 36 days are missing due to the Silkkitie server being offline. Half of these days took place in June and July 2015. During this period, Silkkitie users raised concern that the administrator of Silkkitie, who calls himself Kapteeni ("Captain" in English), had shut down Silkkitie and run off with the remaining Bitcoins. The service continued, however, after a short break.

\subsection{Measures}

For this study we only used sales that took place within Finland by removing items where the seller's location was abroad or seller was willing to sell abroad. The full data includes 93878 observations, and the data covers 286 days of transactions from 260 sellers offering 3823 products. The data includes information on products' prices, the amount in stock and additional details. Drug sales were calculated using the information on available stock. For analytic purposes, the data was organised into panel format and included 16815 daily observations of sellers, including seller's daily drug sales, reputation, capacity and the drugs that the seller had sold during the specific day.

Seller's daily drug sales are the total value of all the products sold in a single day. The median amount of daily sales was 0 , but the mean daily sales were 129 euros/seller. The excess of zero-value days is caused by the fact that many sellers did not make sales on a daily basis. This value is used as an outcome variable in the regression models. 
Silkkitie sellers have categorised their products as stimulants, cannabis, opiates, empathogens, psychedelics, opiates, dissociatives, depressants and other pharmaceuticals (see Table 1 for the specific information). We decided to use this categorisation, which seems to represent experiences that buyers try to gain from the drugs, instead of categorisations based on the chemical formations and legal status.

A seller's reputation quantifies the seller's combined positive and negative feedback (reputation = positive comments - negative comments). The sellers' reputations ranged from -19 to 3418 . However, out of 16815 observations, only $101(0.6 \%)$ were under zero. Based on the 16815 daily observations of sellers, the median capacity was 78 euros. The seller reputation figures for different types of drugs are provided in Table 2 .

A seller's capacity is calculated for each day for each seller. It is based on the total value of the seller's reported stock in euros in a single day (capacity $=\sum_{i=0}^{n}$ price $_{i}$ stock $_{i}$ ), where $\mathrm{n}$ is the total number of producs that the seller is offering. In other words, the seller's capacity is calculated on the basis of the daily product information of each seller. Based on the 16815 daily observations of sellers, the median capacity was 1602 euros. Capacity figures for different types of drugs are provided in Table 2.

\subsection{Statistical analyses}

We first ran descriptive statistics using the full data with a total of 93878 observations. We used Stata 12.0 to run fixed-effects Poisson regression models to analyse the daily drug sales (in euros). These models accounted for both the sellers and the day when the data was gathered, ranging from 1 (5 November 2014) to 268 (23 September 2015).

Poisson regression was selected due to the skewed continuous outcome variable. Although there are several alternatives for treating such outcomes (including a linear regression with log-transformed outcomes), Poisson regression has been argued to provide the best alternative (Santos and Tenreyro, 2006). We ran the models using Huber-White standard errors (i.e., robust standard errors) due to overdispersion (Palmer, 2007). Another option would have been using a fixed-effects negative binomial regression, but there is risk of incidental parameter bias that does not occur with Poisson regression models (Allison, 2012).

The models first report the unadjusted effects of both reputation and availability. We used a square-root transformation for the seller's reputation and a natural logarithmic transformation for the seller's capacity to correct the skewness of these variables. The final models include drug categories as dummy variables $(0=$ no sales in that category, $1=$ at least one sale in that category). Models were checked for multicollinearity; no problems were found in this respect, and sellers' reputations and capacities are both clear and distinct predictors of their daily sales. The results section also reports the daily sales based on the percentiles of the seller's reputation and capacity.

\section{Results}

The total value of the illegal drugs sold on Silkkitie during the 11 months of the study was 2171387 euros, and 41131 items were sold during this period (see Table 2). Stimulants were the most valuable class of drug (538 354 euros), followed by cannabis products (487 111 euros) and empathogens (mostly MDMA; 396127 euros). Depressants were the least sold, with only 4975 euros of sales. Figure 2 shows 
the sales values of different substances during the study. We can see that stimulants, cannabis and empathogens combine to make up over half of all sales during each month.

Out of 3823 products listed, only 51\% were sold. Psychedelics had the highest proportion of sold products (64\%), and opiates had the lowest (38\%). The mean price of the sold products was 84 euros, and the mean daily sales amount per seller was 129 euros, but the largest daily sale by a seller was 85000 euros. High figures in daily sales were, however, very unusual, as 5000 euros/day were exceeded only 10 times, and by only 7 sellers out of a total of 260 sellers. Considering all the sales taking place during the follow-up period of the study, almost $15 \%$ of the sellers did not have sales at all, while the highest selling $15 \%$ were responsible for $82 \%$ of the total sales in Silkkitie.

We used fixed-effects regression models to analyse the associations between a seller's daily sales and his/her reputation and capacity (Table 3). Model 0 reports the unadjusted effects on daily sales due to a seller's reputation and capacity. The models were run separately for both reputation and capacity, which were both positively associated with sales. Model 1 includes both the seller's reputation and capacity in the same model. Model 2 adds the daily sold substances as dummy variables. None of these dummy variables were statistically significant in the model at the level of $p<0.05$; hence, they were not included in Table 3. Model 2 included 222 sellers and 16243 observations in total, for an average of 72.9 daily observations per seller. The model is statistically significant; both seller reputation and capacity were positively associated with daily sales.

Figure 3 shows the changes in daily sales on Silkkitie based on the percentile values of the seller's reputation and capacity (adjusted based on a fixed-effects regression model). The model includes the seller's reputation and capacity as predictors; it is adjusted for the daily sales of different substances. We can see that the (lowest) $10^{\text {th }}$-percentile group in terms of reputation has daily sales of only 62 euros on average and that the (highest) $90^{\text {th }}$-percentile group has sales of 222 euros on average. A similar linear increase is seen for seller's capacity. We can also see that the sales are especially high for the $80^{\text {th }}$ and $90^{\text {th }}$ percentile in terms of reputation.

\section{Discussion}

Our results showed that the illicit drug sales on Silkkitie were worth over 2 million euros during the 11month study. Our main goal in this study was to analyse the impact of the seller's reputation and capacity on daily drug sales. Theoretically, the article was grounded on previous work done on trust systems (Resnick, 2000; Houser and Wooders, 2006; Décary-Hétu and Leppänen, 2013; Lusthaus, 2012) and previous research showing that the seller's reputation has a positive impact on sales in drug markets (Hardy and Norgaard, 2015). We also consider the seller's daily capacity (i.e., the reported sales potential), which has been shown to have an interaction with consumer behaviour (Yu et al., 2015), but this effect has not previously been studied in a cryptomarket setting.

Our Silkkitie findings provide further empirical evidence on the importance of trust systems on cryptomarkets. Higher reputations and capacities indicated higher daily sales. Reputation and capacity represent different facets of information available for the cryptomarket consumers, and they both can be considered an integral part of the trust system in the cryptomarket. The most successful sellers have both a high reputation and a high capacity. Specifically, the capacity figures are dependent on what the sellers have reported as the available stock and we consider them as part of communication with the buyers. It has been also indicated in previous studies that cybercriminals are expected to attract companions in crime through successful communication (Décary-Hétu and Leppänen, 2013). 
It is possible that a seller's reputation and capacity have become even more important due to the instability of cryptomarkets. Within our data, we could see that daily drug sales varied considerably during the study period, many products were not sold at all and that many sellers remained active for only a short period of time. Specifically, risk-averse online consumers might avoid such sellers. At least in our data, this was shown as a concentration of sales towards those sellers who had higher reputations and capacity. Results on reputation and capacity are, however, also valid for the smaller sellers and sales of a variety of drugs.

Silkkitie also provides a very interesting national case that drug markets are changed by the cryptomarkets. Although stimulants, cannabis products and empathogens (e.g., MDMA) were among the most sold products during the study, a wide variety of substances were sold. This follows the general user pattern in Finland. The drug use problem in Finland is characterised by the absence of heroin and by the high prevalence of amphetamine and buprenorphine use (EMCDDA, 2016). Cannabis, amphetamines and MDMA are the most widely used illegal substances in Finland (Hakkarainen et al., 2015). Compared to other widely popular drugs, these substances are more associated with recreational use; opioids and depressants are more popular among marginalised drug users (Pitkänen et al., 2016).

Based on the wastewater analyses, there is an estimate that the size of the Finnish drug market for stimulants (amphetamine, cocaine and methamphetamine) was around 80 million euros in 2014 (Kankaanpää et al., 2016). The cannabis market can be estimated to be somewhere between 20 million and 100 million based on estimations of cannabis use (c.f. Hakkarainen et al., 2006), and there are markets for buprenorphine and benzodiazepines, used most frequently but not only by disadvantaged drug users (Tammi et al., 2011). Considering this, Silkkitie is a major marketplace in Finland. However, most of the drugs in Finland are sold through traditional routes. It is also possible that Silkkitie provides a forum for new types of drug users who would not necessarily buy their drugs from the normal offline markets (Barratt et al., 2016a, 2016b).

According to the Finnish law enforcement, the largest vendor of Silkkitie, called Douppikauppa, was caught in April 2016 when a Finnish Customs unit intercepted a vehicle that was smuggling drugs between the Netherlands and Finland (Finnish Customs, 2016). The car contained several kilos of illegal drugs, including ecstasy tablets, LSD tabs, amphetamine and methamphetamine (Finnish Customs, 2016). This did not disrupt the drug sales on Silkkitie and Valhalla, however. Indeed, the Silkkitie case simply demonstrates again how difficult it is to control and prevent sales in cryptomarkets. Although law enforcement could successfully capture some of the key actors involved, the markets are quickly reestablished (Décary-Hétu and Giommoni, 2017).

Despite the fact that we were able to collect data for almost 11 months, we would like to mention some limitations of our study. We performed data extraction once a day, but on some occasions, we failed to get this data because the Silkkitie server was offline. In addition, we might have missed some information if a seller removed a product from the marketplace between the measurements. Similarly, it is possible that an old product could be registered as new because the seller changed the product title. We believe, however, that these limitations are not critical for our main analyses, which concentrated on seller reputation and capacity. Furthermore, our data is extensive, so the missing data is unlikely to have an impact on the analyses. To our knowledge, our data set is one of the largest one that has been collected from the cryptomarkets. Furthermore, our data set is not vulnerable to the challenges concerning the collection of online data from other platforms, such as the Silk Road. In the Silk Road, for example, incomplete crawls may lead to misleading results (Munksgaard et al., 2016). 
In this study, we were able to follow the extent of trading and produce almost real-time statistics about how people buy and sell illegal drugs. Our method is highly reliable, and the long period of data collection guarantees this reliability. Hence, this study contributes to the increasing body of literature studying cryptomarkets with web crawlers (e.g., Aldridge, 2016; Alridge and Décary-Hétu, 2016; Christin, 2013; Demant et al., 2016; Hardy and Norgaard, 2015). Most important, our results help reveal the consumer interactions between sellers and buyers on online cryptomarkets, and our findings underline the relevance of both reputation and capacity as parts of the cryptomarket trust system. Future studies should continue to collect longitudinal data sets.

\section{References}

Aldridge, J., Décary-Hétu, D., 2016. Hidden wholesale: the drug diffusing capacity of online drug cryptomarkets. Int. J. Drug Policy. 35:7-15.

Allison, P. Beware of software for fixed effects negative binomial regression [Article on the Internet]. City: Publisher; Year [updated 8 June 2012; cited 4 August 2016]. Available from: http://statisticalhorizons.com/fe-nbreg

Bancroft, A., Reid, P.S., 2017. Challenging the techno-politics of anonymity: the case of cryptomarket users. Inf. Commun. Soc. 20:497-512.

Barratt, M.J., Ferris, J.A., Winstock, A.R., 2014. Use of Silk Road, the online drug marketplace, in the United Kingdom, Australia and the United States. Addiction. 109(5):774-83.

Barratt, M.J., Ferris, J.A., Winstock, A.R., 2016a. Safer scoring? cryptomarkets, social supply and drug market violence. Int. J. Drug Policy. 35:24-31.

Barratt, M.J., Lenton, S., Maddox, A., Allen, M. 2016b. 'What if you live on top of a bakery and you like cakes?'-Drug use and harm trajectories before, during and after the emergence of Silk Road. Int. J. Drug Policy. 35:50-57.

Barratt, M. J., Maddox, A. 2016. Active engagement with stigmatised communities through digital ethnography. Qualit. Res. 16:701-19.

Bohannon, J., 2016. Bitcoin busts. Science. 351:1144-6.

Broséus, J., Rhumorbarbe, D., Mireault, C., Ouellette, V., Crispino, F., Décary-Hétu, D. 2016. Studying illicit drug trafficking on Darknet markets: structure and organisation from a Canadian perspective. Forensic Science International 264:7-14.

Caudevilla, F., Ventura, M., Fornís, I., Barratt, M. J., Vidal, C., Quintana, P., ... Calzada, N. (2016). Results of an international drug testing service for cryptomarket users. Int. J. Drug Policy. 35:38-41.

Christin, N., 2013. Traveling the Silk Road: a measurement analysis of a large anonymous online marketplace. In: WWW'13 Proceedings of the 22nd International Conference on World Wide Web, pp. 213-224. New York: ACM. 
Décary-Hétu, D., Giommoni, L. (2017). Do police crackdowns disrupt drug cryptomarkets? A longitudinal analysis of the effects of Operation Onymous. Crime, Law and Social Change 67:55-75.

Décary-Hétu, D., Leppänen, A., 2013. Criminals and signals: An assessment of criminal performance in the carding underworld. Security Journal. 29:442.

Demant, J., Munksgaard, R., Houborg, E. 2016. Personal use, social supply or redistribution? Cryptomarket demand on Silk Road 2 and Agora. Trends in Organized Crime, doi:10.1007/s12117-0169281-4

Dingledine, R., Mathewson, N., Syverson, P., 2004. Tor: the second-generation onion router. Washington, DC: Naval Research Lab.

Duff, C., 2005. Party drugs and party people: examining the 'normalization' of recreational drug use in Melbourne, Australia. Int. J. Drug Policy. 16:161-70.

Dolliver, D.S., 2015 Evaluating drug trafficking on the Tor Network: Silk Road 2, the sequel. Int J Drug Policy. 26:1113-23.

Dolliver, D.S., Kenney, J.L., 2016. Characteristics of Drug Vendors on the Tor Network: A Cryptomarket Comparison. Vict. Offenders. May 2, DOI: 10.1080/15564886.2016.1173158

Dolliver, D.S., Kuhns, J.B. 2016. The Presence of New Psychoactive Substances in a Tor Network Marketplace Environment, J. Psychoact. Drugs. 48: 321-329, DOI: 10.1080/02791072.2016.1229877

European Monitoring Centre for Drugs and Drug Addiction. Finland country overview. Lisbon: EMCDDA; [cited 4 August 2016]. Available from: http://www.emcdda.europa.eu/countries/finland

FBI, 2014. Sealed Complaint against Ross Ulbricht. Narcotic Trafficking Conspiracy.

https://www.documentcloud.org/documents/801103-172770276-ulbricht-criminal-complaint.html

Finnish Customs (2016). Pre-investigation reports of the Douppikauppa Case. 9010/R/6369/15; 9010/R/7463/15; 9010/R/2757/16; 9010/R/3004/16. Tampere: Finnish Customs.

Glassman, M., Kang, M.J., 2012. Intelligence in the internet age: the emergence and evolution of open source intelligence (OSINT). Comp. Hum. Behav. 28:673-82.

Hakkarainen, P., Kainulainen, H., Perälä, J. 2006. Suomen kannabismarkkinat - paljonko pilveä palaa? [Measuring the size of the cannabis market in Finland]. Yhteiskuntapolitiikka. 71: 583-95.

Hakkarainen, P., Karjalainen, K., Ojajärvi, A., Salasuo, M., 2015. Huumausaineiden ja kuntodopingin käyttö ja niitä koskevat mielipiteet Suomessa vuonna 2014 [Drug use, doping and public opinion in Finland: results from the 2014 Drug Survey]. Yhteiskuntapolitiikka. 80(4):319-33. Finnish.

Hardy, R.A., Norgaard, J.R., 2015. Reputation in the Internet black market: an empirical and theoretical analysis of the Deep Web. J. Inst. Econ. 12:515-39.

Houser, D., Wooders, J. 2006. Reputation in auctions: Theory, and evidence from eBay. Journal of Economics \& Management Strategy. 15:353-69. 
Kankaanpää, A., Ariniemi, K., Heinonen, M., Kuoppasalmi, K., Gunnar, T. 2016. Current trends in Finnish drug abuse: Wastewater based epidemiology combined with other national indicators. Sci. Total Environ. Http://dx.doi.org/10.1016/j.scitotenv.2016.06.060

Keipi, T., Oksanen, A. 2014. Self-exploration, anonymity and risks in the online setting. J. Youth Stud. 17:1097-113.

Kristoufek, L., 2015. What are the main drivers of the Bitcoin price? evidence from wavelet coherence analysis. PlosOne. 10:e0123923.

Lusthaus, J., 2012. Trust in the world of cybercrime. Global Crime. 13(2):71-94.

Maddox, A., Barratt, M. J., Allen, M., \& Lenton, S. 2016. Constructive activism in the dark web: cryptomarkets and illicit drugs in the digital 'demimonde'. Inf. Comm. So. 19: 111-26.

Martin, J., 2014a. Drugs on the dark net: how cryptomarkets are transforming the global trade in illicit drugs. Basingstoke \& New York: Palgrave Macmillan.

Martin, J., 2014b. Lost on the Silk Road: online drug distribution and the 'cryptomarket'. Criminol Crim Justice. 14:351-67

Munksgaard, R., Demant, J., Branwen, G., 2016. A. Replication and methodological critique of the study 'Evaluating drug trafficking on the Tor Network'. Int. J. Drug Policy. 35:92-95.

Munksgaard, R., Demant, J. (2016). Mixing politics and crime-The prevalence and decline of political discourse on the cryptomarket. Int. J. Drug Policy. 35:77-83.

Nakamoto, S., 2008. Bitcoin: a peer-to-peer electronic cash system. [cited 4 August 2016]. Available from: http://bitcoin.org/bitcoin.pdf

Palmer, A., Losilla, J.M., Vives, J., Jimenez, R., Llorens, N., 2007. Overdispersion in the Poisson regression model. a comparative simulation study. Methodology. 3:89-99.

Pitkänen, T., Perälä, J., Tammi, T., 2016. Huumeiden käyttäjiä on monenlaisia: kahdensadan helsinkiläisen huumeiden aktiivikäyttäjän elämäntilanne ja päihteiden käyttö [Different kinds of drug users: life situation and substance use of two hundred active drug users in Helsinki]. Tietopuu: Tutkimussarja; 1-10. Finnish.

Resnick, P., Kuwabara, K., Zeckhauser, R., Friedman, E., 2000. Reputation systems. Communications of the ACM. Dec 1;43(12):45-8.

Rhumorbarbe, D., Staehli, L., Broséus, J., Rossy, Q., Esseiva, P. 2016. Buying drugs on a Darknet market: A better deal? Studying the online illicit drug market through the analysis of digital, physical and chemical data. Forensic science international. 267:173-182.

Santos Silva, J.M., Tenreyro, S., 2006. The log of gravity. Rev. Econ. Stat. 88:641-58. 
Spears, R., Postmes, T., Lea, M., Wolbert, A. 2002. When are net effects gross products? the power of influence and the influence of power in computer-mediated communication. J. Soc. Issues. 58:91-107.

Tammi, T., Pitkänen, T., Perälä, J. 2011. Stadin nistit - huono-osaisten helsinkiläisten huumeidenkäyttäjien päihteet sekä niiden käyttötavat ja hankinta [Disadvantaged drug users in Helsinki: what drugs do they use, how do they use them and how do they get them]. Yhteiskuntapolitiikka 76:4554.

The Guardian, 2013. Tor: 'the king of high-secure, low-latency anonymity' [updated 4 Oct 2013; cited 4 August 2016]. Available from: http://www.theguardian.com/world/interactive/2013/oct/04/tor-highsecure-internet-anonymity

Van Buskirk, J., Naicker, S., Roxburgh, A., Bruno, R., Burns, L., 2016. Who sells what? country specific differences in substance availability on the Agora Cryptomarket. Int. J. Drug Policy. Jul 20; DOI 10.1016/j.drugpo.2016.07.004

Van Hout, M.C., Bingham, T., 2013a. 'Silk Road', the virtual drug marketplace: a single case study of user experiences. Int. J. Drug Policy. 24:385-91.

Van Hout, M.C., Bingham, T., 2013b. 'Surfing the Silk Road': A study of users' experiences. Int. J. Drug Policy. 24:524-9.

Van Hout, M. C., \& Hearne, E. (2017). New psychoactive substances (NPS) on cryptomarket fora: An exploratory study of characteristics of forum activity between NPS buyers and vendors. Int. J. Drug Policy 40:102-10.

Yu, M., Kapuscinski, R., Ahn, H.S., 2015. Advance selling: effects of interdependent consumer valuations and seller's capacity. Manag. Sci. 61:2100-17.

Zimmermann, P., 1995. Pretty good privacy: public key encryption for the masses. building in big brother. New York: Springer-Verlag. 
Tables and figures

Table 1: Drug categories in Silkkitie

\begin{tabular}{|c|c|}
\hline Drug category in Silkkitie & Drugs included \\
\hline Stimulants & $\begin{array}{l}\text { Amphetamine, cocaine, metamphetamine, } \\
\text { A-PVP, cathinones, crack, MDPV, 2- } \\
\text { FMA/4-FA, 4-MePPP, phenidates, nicotine, } \\
\text { coffeine, snuff }\end{array}$ \\
\hline Cannabis & $\begin{array}{l}\text { Weed, hash, edibles, concentrates, leaf, } \\
\text { synthetics }\end{array}$ \\
\hline Emphatogens & Ecstasy, MDMA, MDA/MDAI, methylone \\
\hline Psychedelics & $\begin{array}{l}\text { LSD, DMT/AMT, mushrooms, 25x- } \\
\text { NBOMe, ayahuasca, mescaline, 2C-x, 2C- } \\
\text { T-x, 5-MeO-DiPT, 5-MeO-MiPT, bromo- } \\
\text { dragonfly, LSA/LSZ, AL-LAD, Ibogaine, } \\
\text { Dox }\end{array}$ \\
\hline Other pharmaceutics & $\begin{array}{l}\text { Benzodiazepines, erectile dysfunction } \\
\text { drugs, sleeping pills, ADHD medication, } \\
\text { pain, sedatives, muscle relaxants, MAOIs, } \\
\text { nootropics }\end{array}$ \\
\hline Opiates & $\begin{array}{l}\text { Heroin, buprenorphine, oxycodone, } \\
\text { fentanyl, tramadol, codeine, morphine, } \\
\text { opium, metadon }\end{array}$ \\
\hline Dissociatives & Ketamine, salvia, MXE/MXP, datura \\
\hline Depressants & GHB/GBL, alcohol \\
\hline
\end{tabular}


Table 2: Descriptive information about sales on Silkkitie during the 11-month study period

\begin{tabular}{|c|c|c|c|c|c|c|c|c|c|}
\hline & $\begin{array}{c}\text { Total } \\
\text { sales }(€)\end{array}$ & $\begin{array}{c}\text { Items } \\
\text { sold }\end{array}$ & $\begin{array}{c}\text { Different } \\
\text { products } \\
\text { on sale }\end{array}$ & $\begin{array}{c}\text { \% of } \\
\text { sold } \\
\text { products }\end{array}$ & $\begin{array}{c}\text { Median } \\
\text { product } \\
\text { price }\end{array}$ & $\begin{array}{l}\text { Median } \\
\text { price of } \\
\text { products } \\
\text { sold }\end{array}$ & $\begin{array}{c}\text { Median } \\
\text { seller } \\
\text { reputation }\end{array}$ & $\begin{array}{c}\text { Median } \\
\text { seller } \\
\text { reputation } \\
\text { (during the } \\
\text { day the sale } \\
\text { took place) }\end{array}$ & $\begin{array}{c}\text { Median } \\
\text { seller } \\
\text { capacity } \\
\text { per } \\
\text { product }\end{array}$ \\
\hline Stimulants & 538354 & 7242 & 529 & 52 & 80 & 48 & 153 & 203 & 1165 \\
\hline Cannabis & 487111 & 8878 & 807 & 62 & 70 & 55 & 116 & 131 & 648 \\
\hline Emphatogens & 396127 & 8424 & 236 & 53 & 99 & 70 & 368 & 476 & 3645 \\
\hline Psychedelics & 336010 & 5826 & 261 & 64 & 50 & 40 & 537 & 617 & 900 \\
\hline $\begin{array}{c}\text { Other } \\
\text { pharmaceuticals }\end{array}$ & 180728 & 6244 & 1113 & 50 & 32 & 23 & 63 & 67 & 140 \\
\hline Opiates & 181316 & 3734 & 804 & 38 & 70 & 43 & 368 & 476 & 388 \\
\hline Dissociatives & 46766 & 632 & 38 & 47 & 70 & 68 & 1732 & 1778 & 1878 \\
\hline Depressants & 4975 & 151 & 35 & 49 & 85 & 60 & 156 & 539 & 630 \\
\hline Total & 2171387 & 41131 & 3823 & 51 & 55 & 39 & 120 & 139 & 488 \\
\hline
\end{tabular}

Note: figures are based on 93878 observations.

Table 3: Reputation and availability explaining daily sales on Silkkitie (based on fixed-effects Poisson regression models)

\begin{tabular}{|c|c|c|c|c|c|c|c|c|}
\hline & Reputation & & & & Capaci & & & \\
\hline Model & Coeff. & $\begin{array}{l}\text { Robust } \\
\text { SE }\end{array}$ & $\mathbf{Z}$ & $\boldsymbol{P}$ & Coeff. & $\begin{array}{l}\text { Robust } \\
\text { SE }\end{array}$ & $\mathbf{Z}$ & $\boldsymbol{P}$ \\
\hline 0 & 0.029 & 0.012 & 2.51 & 0.012 & 0.209 & 0.047 & 4.49 & $<0.001$ \\
\hline 1 & 0.024 & 0.011 & 2.27 & 0.023 & 0.199 & 0.043 & 4.65 & $<0.001$ \\
\hline 2 & 0.025 & 0.010 & 2.52 & 0.012 & 0.120 & 0.055 & 2.18 & 0.029 \\
\hline
\end{tabular}

Note: Model 0 shows unadjusted effects for both reputation and capacity separately. Model 1 includes reputation and capacity in the same model, and Model 2 adds the daily sold substances as controls. The final model 2 included 222 sellers and 16243 observations (observations per seller: minimum 2, maximum 267, mean 72.9) 


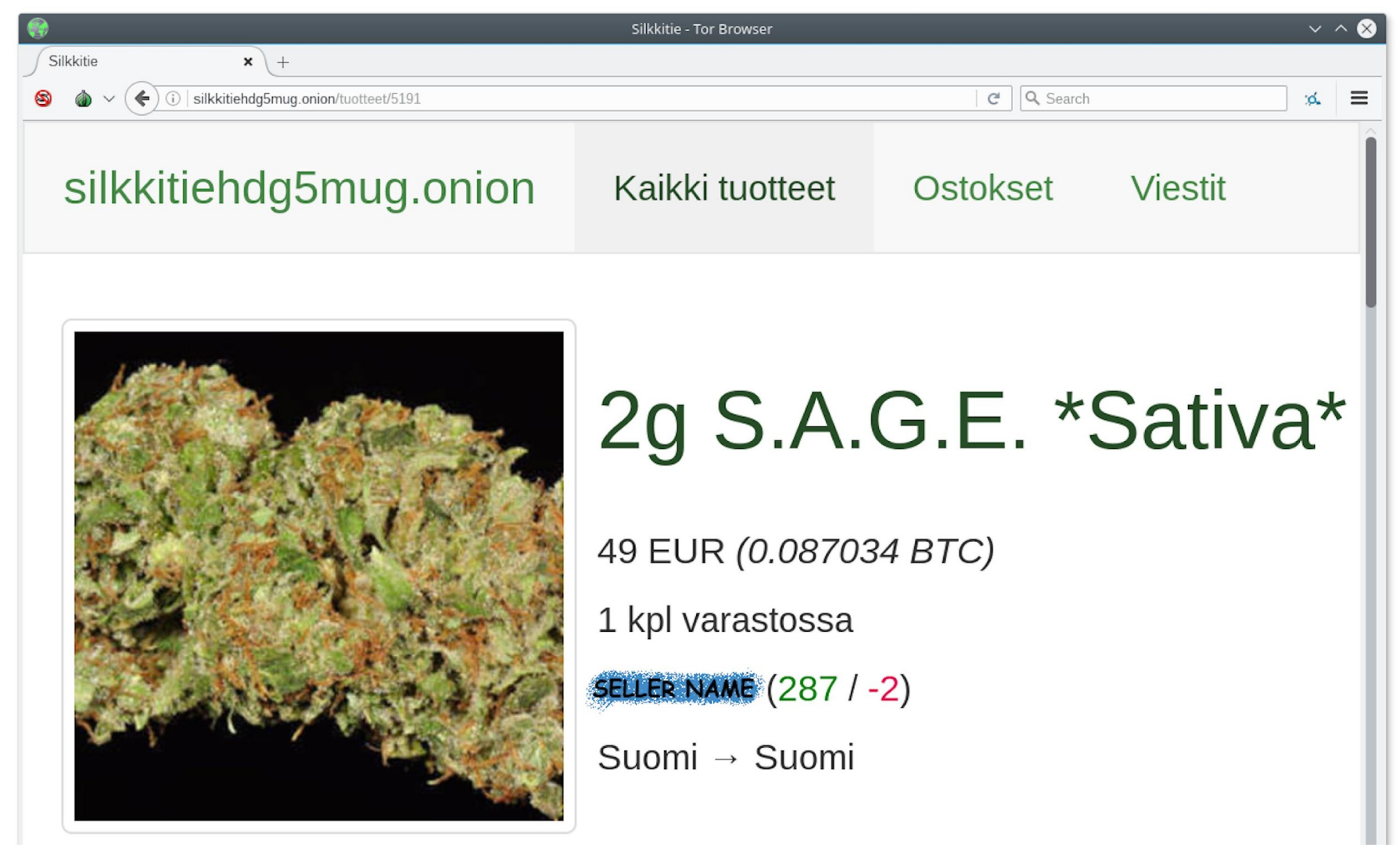

Figure 1: Example screenshot from Silkkitie, with the seller's positive and negative feedback in parentheses following the seller's name 


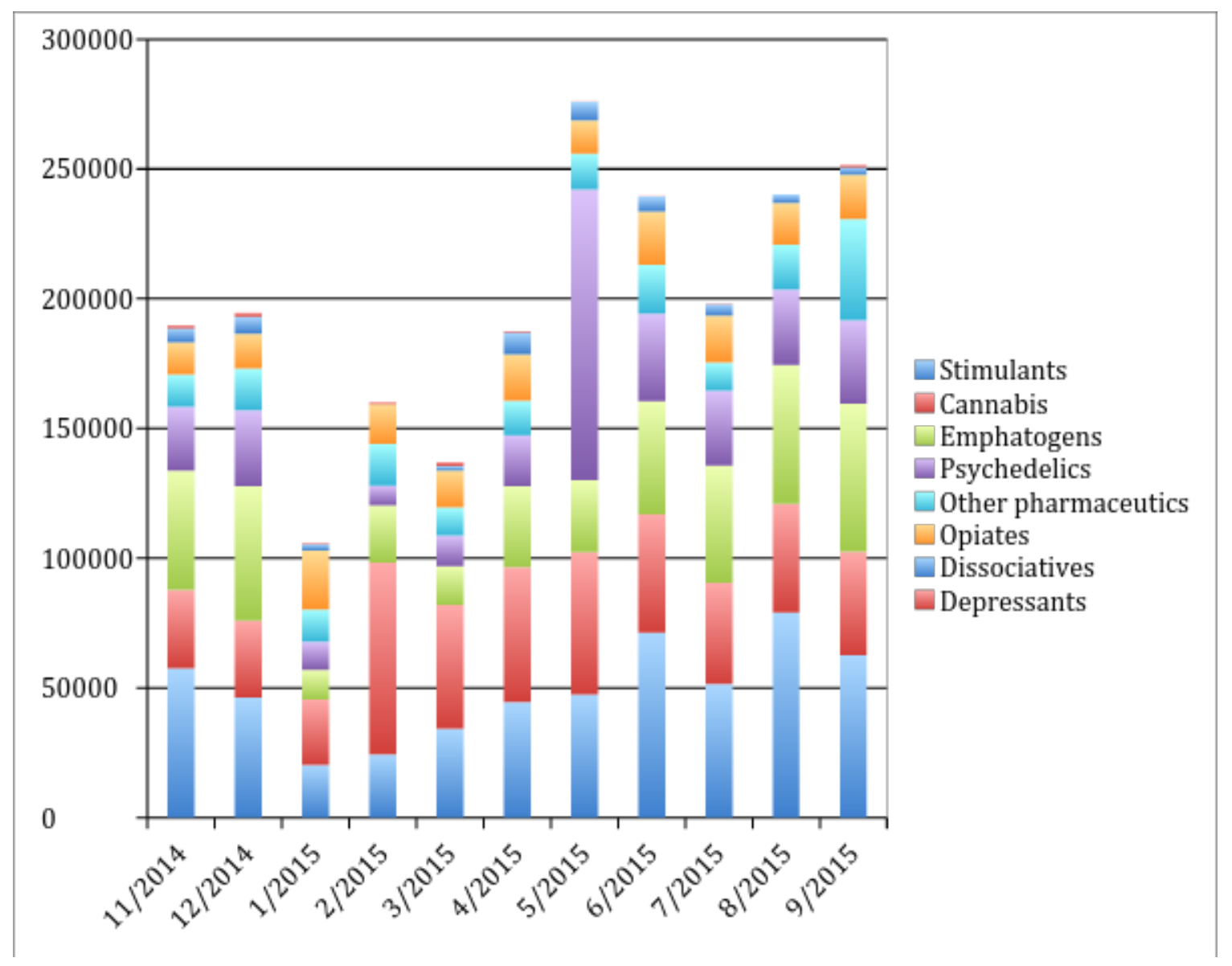

Figure 2: Sales of different substances on Silkkitie between 5 November 2014 and 26 September 2015 


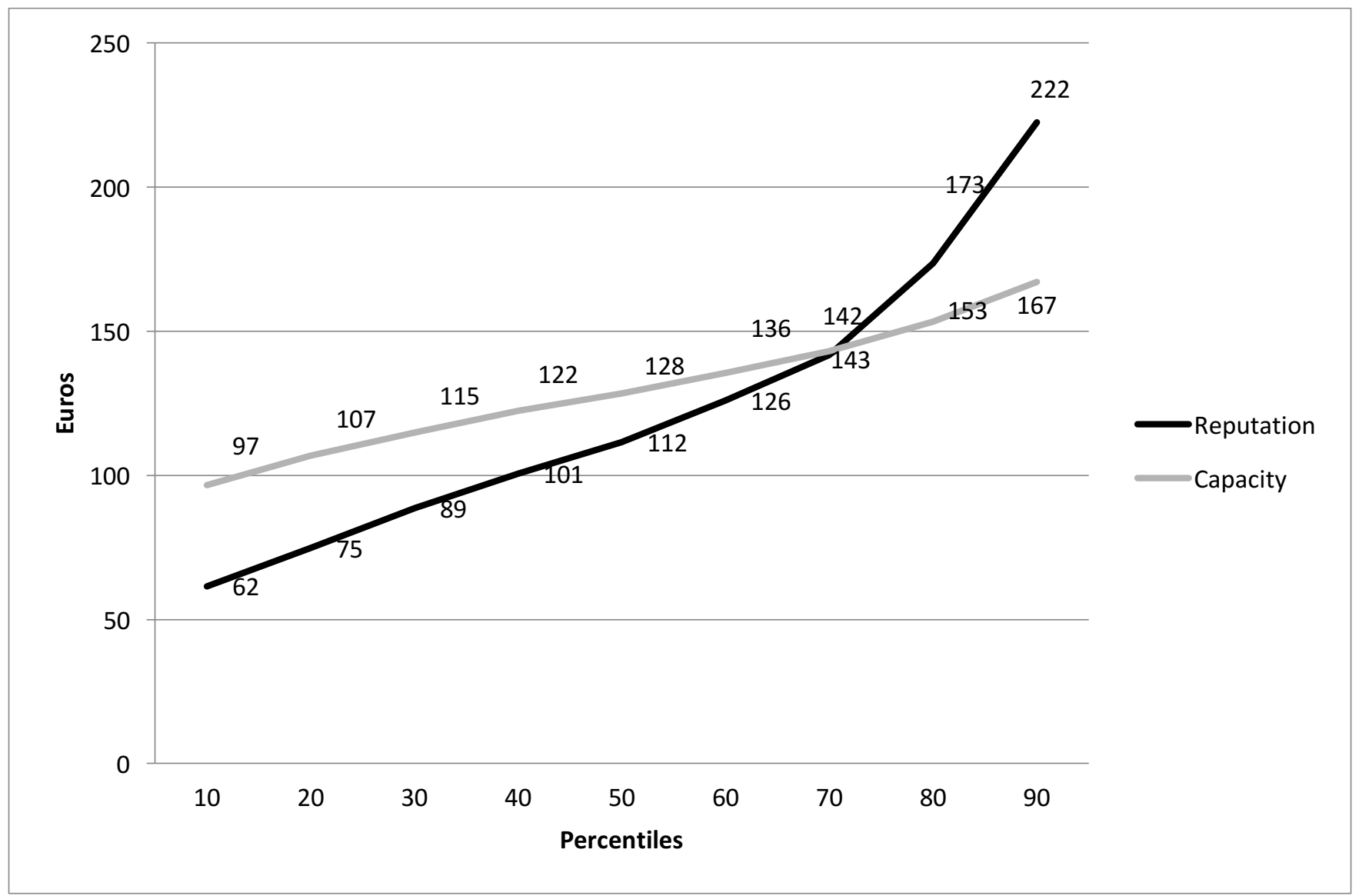

Figure 3: Change in daily sales on Silkkitie based on percentile values of reputation and availability (adjusted predictions based on fixed-effects regression models) 